\title{
Strategi Pengembangan Pariwisata di Wisata BALKONDES Ngadiharjo di Kawasan Borobudur Kabupaten Magelang
}

Rian Destiningsih a, 1, Andhatu Achsa a, 2, Dian Marlina Verawati a, 3

${ }^{1}$ riandestiningsih@untidar.ac.id, ${ }^{2}$ andhatuachsa@untidar.ac.id,33 dianmarlina86@untidar.ac.id

a Program Studi S1 Ekonomi Pembangunan, Fakultas Ekonomi, Universitas Tidar, Jl. Kapten Suparman 39 Potrobangsan, Jawa Tengah 56116 Indonesia

\section{Abstract}

Magelang has so many tours, nice and very interesting to visit. Balai Ekonomi Desa which is often abbreviated as Balkondes, is a tour that is only found in Magelang. Several tours feature Balkondes, but the destinations carried are different from Balkondes. Balkondes is the embodiment of the village community in developing the economic potential of the village, while the number of Balkondes in Magelang Regency is around 20 Balkondes. One of them, Balkondes Ngadiharjo is one of Balkondes that is unique and still frequently visited by tourists often as tourists. The purpose of this research is provide an overview to identify tourism development strategy in Balkondes Ngadiharjo. The method of the study used descriptive qualitative, Strengths-Weaknesses-Opportunities-Threats (SWOT) and the survey was undertaken on 57 respondents. The results showed that alternative development strategies for Balkondes Ngadiharjo include optimization of promotions, internet access, suitable facilities gave the wide location, environment-based tourism, outdoor events and the tendency to travel in eco-based niche tourism, Borobudur Temple tourists to visit Balkondes Ngadiharjo, increasing creativity Balkondes Ngadiharjo's innovation and uniqueness to maintain competition for the number of visitors between Balkondes and other tours, increase management professionalism, playgrounds, public facilities and innovation and creativity to maintain competition between Balkondes and other tourist objects so that the level of tourist visits is high and can give a positive impression that is memorable for visitors and have an impact on the high profitability of tourist objects.

Keyword: balkondes, tourism, strategy, swot

\section{PENDAHULUAN}

Pariwisata sebagai penggerak perekonomian sudah mendapat perhatian yang besar. Hal tersebut dikarenakan pariwisata dapat memberikan efek multiplier positif kepada masyarakat, misalnya dengan penyerapan tenaga kerja. Indonesia berpotensi dalam sektor pariwisata karena luas kepulauan yang membentang (Bahiyah et al., 2018). Dilihat dari data yang dipublikasikan Badan Pusat Statistik (BPS), kunjungan wisatawan asing meningkat setiap tahunnya walaupun belum mencapai target yang diinginkan; namun di tahun 2019, Indonesia terpilih menjadi destinasi wisata halal terbaik dunia dari Global Muslim Travel Index (GMTI) (Badan Pusat Statistik, 2019).

Pariwisata tidak hanya didorong oleh pemerintah pusat saja tetapi juga pemerintah daerah. Provinsi Jawa Tengah misalnya, letak yang strategis diantara provinsi lain di Pulau Jawa. Melihat data realisasi penerimaan pajak di Jawa Tengah tahun 2018 yang berkaitan dengan pariwisata yaitu pajak kebudayaan, hiburan dan rekreasi sebagai peringkat ketiga pajak terendah. Dimana peringkat pertama terendah yaitu jasa perorangan yang melayani rumah tangga, kegiatan yang menghasilkan barang dan jasa oleh rumah tangga yang digunakan sendiri untuk memenuhi kebutuhan; sedangkan peringkat keduanya yaitu kegiatan badan internasional dan badan ekstra internasional lainnya (BPS Provinsi Jawa Tengah, 2018). Hal menarik lainnya dilihat dari tingkat hunian kamar pada hotel menurut provinsi, Jawa Tengah kembali menempati posisi terendah ketujuh dari seluruh provinsi di Indonesia tahun 2018 (Badan Pusat Statistik Indonesia, 2019).
Pariwisata pada tingkat daerah biasanya mendayagunakan sumberdaya yang ada pada tingkat daerah misalnya sumberdaya alam dan sumberdaya manusia. Tujuannya yaitu untuk mendorong atau mengangkat perekonomian daerah, mengenalkan budaya yang ada supaya lebih dikenal oleh masyawakat awam (Deddy Prasetya Maha Rani, 2014).

Kabupaten Magelang dengan wisata yang popular yaitu wisata Candi Borobudur. Wisata tersebut tidak hanya memberikan dampak positif terhadap perkonomian masyarakat sekitar tetapi juga kepada masyarakat di Kawasan Borobudur secara lebih luas. Hal tersebut dibuktikan dengan didirikannya lebih dari 20 balai ekonomi desa (Balkondes) di sekitar Kawasan Candi Borobudur. Adapun nama-nama Balkondes tersebut antara lain Balkondes Desa Kenalan, BNI Wanurejo, Borobudur, Bumiharjo, Candirejo, Coklat nDeso Bigaran, Desa Karangrejo, Duta Menoreh Desa Tanjungsari, Giripurno, Giritengah, Kebonsari, Kembanglimus, Majaksingi Jasa Marga, Ngadiharjo, Ngargogondo, Salam, Sambeng. Tuksongo (Digital Telkom), Wringinputih, Saka Pitu Tegalarum, Karanganyar.

Balkondes Ngadiharjo merupakan salah satu Balkondes yang banyak diminati oleh wisatawan. Hal tersebut karena keunikan pemandangan dan ornamenornamen yang menarik bagi kaum milenial untuk dibagikan melalui media sosialnya. Daya tarik sebuah wisata menjadi hal yang penting karena tanpa ketertarikan konsumen atau wisatawan terhadap sebuah wisata maka kemajuan dari wisata tersebut akan kurang 


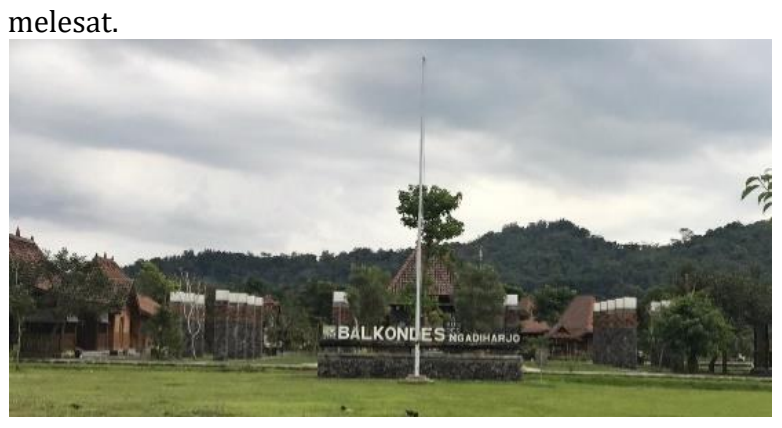

Gambar 1. Balkondes Ngadiharjo

Berdasarkan latarbelakang tersebut, tujuan penelitian ini yaitu mengidentifikasi strategi pengembangan Balkondes Ngadiharjo.

\section{METODE PENELITIAN}

Penelitian ini termasuk kedalam penelitian kualitatif dengan tipe studi kasus. Studi kasus merupakan pendekatan yang fokus pada individu atau kelompok tertentu dengan penyelidikan pada suatu kondisi tertentu guna menjelaskan kondisi tertentu (Prihatsanti et al., 2018). Pengambilan data dilakukan menggunakan kuisioner pada responden. Dalam penelitian ini responden yaitu orang yang pernah mengunjungi Balkondes Ngadiharjo minimal satu kali. Reponden yang digunakan dalam penelitian ini sebanyak 57 responden. Pemilihan sampel menggunakan teknik sampling aksidental yaitu pemilihan responden yang secara kebetulan bertemu ketika sedang menyebarkan kuisioner di Balkondes Ngadiharjo, responden tersebut digunakan sebagai sampel apabila sesuai sebagai sebagai sumber data (Darmanahia, 2019). Analisis SWOT merupakan alat analisis yang digunakan untuk menganalisis lingkungan strategis, yaitu lingkungan internal (strenght dan weakness) dan eksternal (opportunity dan treath)(Nurcahya \& Alexandri, 2020; Rah Adi Fahmi et al., 2018). Analisis SWOT memiliki manfaat dalam analisis strategi, dalam artikel ini fokus pada pengembangan pariwisata di wisata balkondes ngadiharjo di kawasan borobudur kabupaten magelang, sehingga diharapkan dapat meminimalkan weakness dalam pengembangan balkondes tersebut. Periode penelitian dilaksanakan pada bulan Mei - Juni tahun 2020. Kuisioner terdiri dari enam pokok pertanyaan. Pokok-pokok tersebut antara lain mengenai pertanyaan biodata responden, frekwensi kunjungan, tujuan kunjungan, keunikan, fasilitas yang tersedia, aksesibilitas.

\section{HASIL DAN PEMBAHASAN}

Pariwisata merupakan salah satu sektor yang dapat menopang ekonomi nasional, pariwisata juga mampu mengurangi pengangguran (Pajriah, 2018). Hal tersebut dikarenakan dengan adanya pengembangan pariwisata, maka akan berkembang juga sebuah wilayah dimana akan tercipta lapangan pekerjaan dan lapangan pekerjaan sebagai efek multiplier dari pengembangan atau pembangunan pariwisata di wilayah tertentu. Elemen-elemen yang ada didalam pariwisata antara lain wisatawan, wilayah tujuan, perjalanan, industri dan lain-lain (Devy \& Soemanto, 2017).

Balkondes dibentuk oleh Kementerian BUMN dalam rangka peningkatan perekonomian masyarakat di kawasan borobudur (Cholisna et al., 2019). Setelah proses pembangunan, Balkondes diserahkan, dikelola dan dikembangkan oleh masyarakat (Hidayah \& Agustinah, 2019). Harapannya Balkondes bisa menjadi penggerak pengembangan industri rumah tangga sekitar sehingga mampu memberikan manfaat jangka panjang baik terhadap masyarakat secara umum maupun industri sekitar (Muafi et al., 2018). Balkondes Ngadiharjo adalah balkondes binaan perusahaan listrik negara (PLN).

\section{A. Gambaran Umum Responden Balkondes} Ngadiharjo

Responden dalam hal ini orang yang pernah berkunjung ke Balkondes Ngadiharjo setidaknya satu kali. Dalam penelitian ini repsonden sebanyak 57 orang didominasi jenis kelamin perempuan yaitu sebesar 80,7 persen dan sisanya laki-laki sebesar 19,3 persen. Usia responden sebesar 96,49 persen 16-25 tahun, sisanya berusia lebih dari 26 tahun.

Pendidikan yang sudah ditamatkan reponden sebesar 75,44 persen berpendidikan SMA, dan sisanya 24,66 persen berpendidikan Sarjana. Balkondes Ngadiharjo yang terletak di Kabupaten Magelang tidak hanya dikunjungi oleh orang berdomisili Magelang saja akan tetapi dari daerah lain seperti Kota Magelang, Kota Bekasi, Kabupaten Batang, Gunungkidul, DIY, Tasikmalaya, Depok, Tangerang, Kabupaten Temanggung, dan juga Kabupaten Batang. Meskipun responden berdomisili di Kabupaten Magelang mencapai 61,4 persen, dan sisanya berasal dari daerah lain.

\section{B. Gambaran Frekwensi Kunjungan Responden Ke Balkondes Ngadiharjo}

Responden berkunjung ke Balkondes Ngadiharjo sebanyak satu kali sebesar 42,11 persen, sebanyak dua kali sebesar 21,05 persen, dan sisanya pernah berkunjung sebanyak 3 hingga lebih dari 5 kali sebanyak 36,84 persen. Sebesar 87,72 persen responden menikmati ketika ketika berkunjung, hal tersebut dibuktikan dengan jawaban ketika diberi pertanyaan akan datang pada kesempatan berikutnya atau tidak dan rata-rata menjawab iya. Dan semua responden juga akan memberikan info kepada kerabat atau teman untuk berkunjung ke Balkondes Ngadiharjo.

\section{Gambaran Tujuan Kunjungan Responden Ke Balkondes Ngadiharjo}

Informasi mengenai Balkondes Ngadiharjo didapat responden dari beberapa cara antara lain website, instagram, facebook, twitter, kerabat, tinggal darerah Kawasan Candi Borobudur. Adapun tujuan responden berkunjung antara lain berlibur, acara keluarga, kegiatan kemahasiswaan, acara pernikahan, buka bersama, kegiatan komunitas, serta nonton konser. Kunjungan ke balkondes berasal dari paket wisata dan secara pribadi yang memang tertarik dengan Balkondes Ngadiharjo, sebesar 96,49 persen berkunjung karena ketertarikannya pada balkondes ini.

\section{Gambaran Keunikan Balkondes Ngadiharjo}

Keberagaman jenis atau wahana yang disediakan memberikan pengaruh kepada keberlanjutan sebuah tempat wisata. Sebesar 56,14 persen responden beranggapan bahwa wisata ini sudah memiliki keberagaman jenis atau wahana wisata. Namun responden mmerasa fasilitas yang disediakan kurang 
maksimal. Karakteristik atau ciri khas balkondes ini dibandingkan dengan yang lain antara lain suasana tenang, asri, sejuk, nyaman, akses mudah, estetik, instagramable, tempatnya luas cocok untuk pentas seni, makanan minuman beragam, banyak spot foto, wisata murah, bangunan khas atau rumahnya unik, rumah joglo kesan modern, pemandangan perbukitan menorah, ornamen tiang-tiang tinggi sebagai spot foto, dan malam hari menyala, rumahnya bebahan dasar kayu dan batu, penginapan atau sewa rumah.

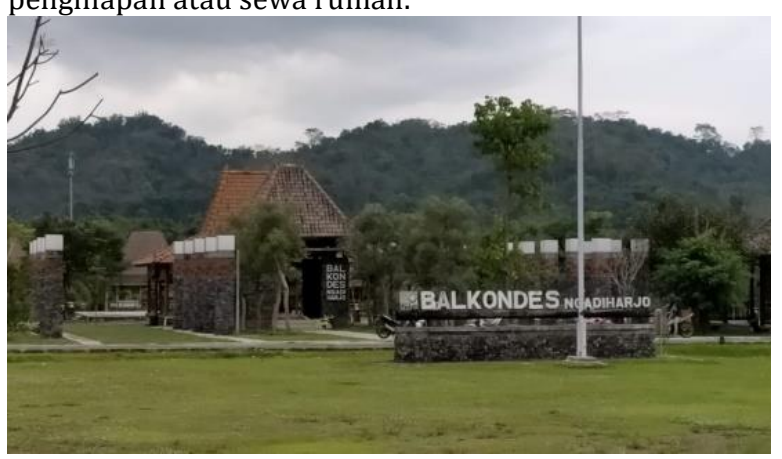

Gambar 2. Tiang-tiang Balkondes Ngadiharjo

E. Gambaran Fasilitas Yang Tersedia Menurut Responden Di Balkondes Ngadiharjo

Pelayanan yang diberikan kepada konsumen dirasa sudah baik, dilihat dari jawaban responden yang menyatakan sikap ramah sebesar 87,71 persen serta dalam hal kesiapsiagaan tinggi (cekatan dalam hal melayani dan menangani komplain) sebesar 50,88 persen. Terkait fasilitas parkir di Balkondes Ngadiharjo dirasa cukup luas oleh para responden, kemanannyapun terjaga dikarenakan ada petugas parkir yang mengawasi kendaraan mereka. Terkait fasilitas toilet umum, responden menggap sudah bersih, namun sebesar 26,32 persen menganggap kurang bersih dan tidak bersih. Terkait fasilitas penginapan dirasa nyaman, bersih dan lengkap oleh para responden. Terkait fasilitas makanan, responden merasa harga makanan cukup wajar, beragam makanannya dan dijual juga makanan khas Magelang di area balkondes, serta di Balkondes
Ngadiharjo juga menjual souvenir atau buah tangan ciri khas balkondes ini. Kekurangan dalam hal fasilitas yang disediakan antara lain kurang disediakannya tempat untuk duduk santai, banyak pengunjung balkondes yang mengganggu orang yang menginap dengan megambil gambar di teras penginapan, kurangnya bunga atau pohon sehingga ketika siang hari terik matahari terasa menyengat, kondisi toilet yang sempit dan kurang nyaman, belum adanya fasilitas wifi, area parkir luas namun tidak teratta dnegan baik sehingga pengunjung bebas memarkirkan kendaraanya.

\section{F. Gambaran Aksesibilitas Ke Balkondes \\ Balkondes Ngadiharjo}

Aksesibilitas atau perpindahan dari satu wisata ke wisata lainnya dengan mudah (Tingginehe; et al., 2019). Aksesibilitas dalam hal ini kondisi jalan dan petunjuk jalan menuju balkondes. Responden beranggapan bahwa akses jalan menuju Balkondes Ngadiharjo dalam kondisi sedang dengan persentase sebesar 57,89 persen, dan sisanya beranggapan baik sebesar 35,09 persen, serta sisanya beranggapan kondisi jalan sangat kurang baik sebesar 7, 02 persen. Kondisi jalan tersebut didukung adanya petunjuk jalan yang jelas dan dalam jumlah banyak, hal tersebut karena untuk menuju balkondes ini membutuhkan ketelitian dalam melihat petunjuk jalan. Untuk mensiasatinya bisa dilakukan promosi melalui kegiatan seni atau pertunjukan, sehingga lebih banyak calon konsumen yang mengenal dan mengetahui letak pasti Balkondes Ngadiharjo.

\section{G. Strategi Pengembangan Pariwisata Balkondes Ngadiharjo}

Dalam menyusun strategi pengembangan pariwisata di Balkondes Ngadiharjo digunakan pendekatan SWOT atau Strengths-WeaknessesOpportunities-Threats. Analisis ini didasarkan pada logika yang dapat memaksimalkan kekuatan namun secara bersamaan dapat meminimalkan kelemahan dan ancaman.

Tabel 4.1 Matriks SWOT Balkondes Ngadiharjo

\begin{tabular}{|c|c|c|}
\hline \multirow[t]{11}{*}{ INTERNAL } & STRENGTH/KEKUATAN (S) & WEAKNESS/KELEMAHAN (W) \\
\hline & $\begin{array}{l}\text { Memiliki daya tarik dari pemandangan, } \\
\text { kreatififitas dekorasi, serta penataan letak, }\end{array}$ & $\begin{array}{l}\text { Kurangnya profesionalitas pengelolaan } \\
\text { objek wisata }\end{array}$ \\
\hline & $\begin{array}{l}\text { Memiliki ciri khusus atau khas diantara } \\
\text { Balkondes lainya }\end{array}$ & Kurangnya inovasi dan kreatifitas \\
\hline & Tarif masuk yang sangat terjangkau & Promosi yang belum masif \\
\hline & Lokasi yang luas cocok untuk event yang besar & Kurangnya wahana yang ditawarkan \\
\hline & $\begin{array}{l}\text { Terdapat penginapan yang terjangkau dan } \\
\text { bersih }\end{array}$ & Kecilnya keuntungan setiap bulannya \\
\hline & $\begin{array}{l}\text { Adanya paket wisata yang berkerjasama dengan } \\
\text { wisata di sekitarnya }\end{array}$ & $\begin{array}{l}\text { Pelayanan/fasilitas yang disediakan } \\
\text { kurang memberikan pegalaman yang } \\
\text { mengesankan }\end{array}$ \\
\hline & $\begin{array}{l}\text { Dikelola oleh masyarakat sekitar sehingga sense } \\
\text { belonging tinggi }\end{array}$ & Kurangnya petunjuk jalan \\
\hline & $\begin{array}{l}\text { Pelayanan dan masyarakat sekitar Balkondes } \\
\text { yang ramah }\end{array}$ & Tempat ibadah serta toilet yang sempit \\
\hline & $\begin{array}{l}\text { Beragam kuliner serta terdapat makanan khas } \\
\text { yang dipasarkan }\end{array}$ & \\
\hline & $\begin{array}{l}\text { Terdapat souvenir yang dijualbelikan sesuai } \\
\text { khas Balkondes Ngadiharjo }\end{array}$ & \\
\hline
\end{tabular}




\begin{tabular}{|c|c|c|}
\hline EKSTERNAL & & \\
\hline $\begin{array}{l}\text { OPPORTUNITIES/PE } \\
\text { LUANG (0) }\end{array}$ & STRATEGI S-O & STRATEGI W-O \\
\hline $\begin{array}{lr}\text { Lokasi yang berada di } \\
\text { satu } & \text { kecamatan } \\
\text { dengan } & \text { Candi } \\
\text { Borbudur } & \end{array}$ & $\begin{array}{l}\text { Mengoptimakan keberadaan Balkondes yang } \\
\text { berada pada satu Kecamatan dengan Candi } \\
\text { Borobudur serta daya tarik dan kekhasan } \\
\text { Balkondes untuk menarik pengunjung dalam } \\
\text { jumlah yang lebih tinggi yang mencakup segala } \\
\text { usia melalui berbagai promosi dengan } \\
\text { memanfaatkan tingginya akses internet } \\
\text { sehingga dapat meningkatkan dampak positif } \\
\text { perekonomian masyarakat sekitar (S1, S2, 01, } \\
\text { 09, 010) }\end{array}$ & $\begin{array}{l}\text { Mengoptimalkan banyaknya wisatawan } \\
\text { Candi Borobudur untuk berwisata ke } \\
\text { Balkondes Ngadiharjo melalui promosi } \\
\text { yang masif dengan biaya yang murah } \\
\text { untuk mencapai tingkat keuntungan yang } \\
\text { tinggi (W3,W5, 01) }\end{array}$ \\
\hline $\begin{array}{l}\text { Kecenderungan } \\
\text { berwisata yang beralih } \\
\text { dari mass tourism ke } \\
\text { niche tourism berbasis } \\
\text { lingkungan }\end{array}$ & $\begin{array}{l}\text { Mengoptimalkan rendahnya tarif tiket masuk, } \\
\text { paket wisata, keindahan dan luasnya lokasi serta } \\
\text { ketersediaan fasilitas yang cocok untuk } \\
\text { bermacam event berbagai kelompok (S3, S4, S5, } \\
\mathrm{S6}, 06,07,08)\end{array}$ & $\begin{array}{l}\text { Mengoptimalkan } \\
\text { organisasi/kelompok yang menggelar } \\
\text { outdoor event dan kecenderungan } \\
\text { berwisata niche tourism berbasis } \\
\text { lingkungan serta tingginya keinginan } \\
\text { wisatawan untuk berkunjung kembali dan } \\
\text { merekomendasikan kepada orang lain } \\
\text { dengan dimbangi oleh ketersediaan } \\
\text { wahana yang manarik serta fasilitas yang } \\
\text { memadai (W4, W6,W8, } 02,3,04,06)\end{array}$ \\
\hline $\begin{array}{l}\text { Keinginan untuk } \\
\text { merekomendasikan } \\
\text { orang lain untuk } \\
\text { berkunjung }\end{array}$ & $\begin{array}{l}\text { Mengajak masyarakat sekitar untuk ikut } \\
\text { berperan aktif dalam kegiatan promosi serta } \\
\text { menjaga dan meningkatkan sense belonging, } \\
\text { keramahan serta dukungan masyarakat sekitar } \\
\text { yang secara tidak langsung memberikan kesan } \\
\text { positif sehingga memunculkan keinginan } \\
\text { pengunjung untuk kembali dan } \\
\text { merekomendasikan kepada orang lain (S7, S8, } \\
03,04,05,08)\end{array}$ & \\
\hline $\begin{array}{lr}\text { Terdapat keinginan } \\
\text { pengunjung untuk } \\
\text { berkunjung kembali }\end{array}$ & $\begin{array}{l}\text { Mengoptimalkan kecenderungan wisatawan } \\
\text { yang beralih dari mass tourism ke niche tourism } \\
\text { berbasis lingkungan untuk memperoleh } \\
\text { wisatawan yang lebih banyak dengan } \\
\text { menawarkan pemandangan alam yang menarik, } \\
\text { berbagai kuliner dan souvenir serta kekhasan } \\
\text { yang dimiliki Bakondes Ngadiharjo (S1, S2, S9, } \\
\text { S10,02) }\end{array}$ & \\
\hline $\begin{array}{lr}\begin{array}{l}\text { Adanyan } \\
\text { dari }\end{array} & \begin{array}{r}\text { dukungan } \\
\text { sekitar }\end{array} \\
\end{array}$ & & \\
\hline $\begin{array}{l}\text { Banyaknya organisasi, } \\
\text { instansi maupun } \\
\text { kelompok yang ingin } \\
\text { menyelenggarakan } \\
\text { acara secara outdoor }\end{array}$ & & \\
\hline $\begin{array}{l}\text { Tingginya akses } \\
\text { internet diera digital }\end{array}$ & & \\
\hline $\begin{array}{l}\text { Biaya promosi yang } \\
\text { murah menggunakan } \\
\text { media sosial } \\
\text { (instagram, whatsapp, } \\
\text { facebook \& website) } \\
\text { serta dari mulut ke } \\
\text { mulut }\end{array}$ & & \\
\hline $\begin{array}{lcc}\text { Dapat dinikmati } & \text { oleh } \\
\text { semua usia } & \text { dan } \\
\text { kalangan } & & \\
\end{array}$ & & \\
\hline
\end{tabular}


Vol. 8 No 2, 2020

\begin{tabular}{|c|c|c|}
\hline $\begin{array}{l}\text { Memberikan manfaat } \\
\text { ekonomi } \\
\text { masyarakat sekitar }\end{array}$ & & \\
\hline $\begin{array}{l}\text { THREATS/ } \\
\text { ANCAMAN(T) }\end{array}$ & STRATEGI S-T & STRATEGI W-T \\
\hline $\begin{array}{l}\text { Banyaknya persaingan } \\
\text { antar Balkondes dan } \\
\text { wisata lain yang ada di } \\
\text { Magelang }\end{array}$ & $\begin{array}{l}\text { Meningkakan kreatifitas, inovasi serta kekhasan } \\
\text { yang dimiliki Balkondes Ngadiharjo untuk } \\
\text { menjaga persaingan jumlah pengunjung antar } \\
\text { Balkondes dan wisata lainnya } \\
(\mathrm{S} 1, \mathrm{~S} 2, \mathrm{~T} 1, \mathrm{~T} 2, \mathrm{~T} 4, \mathrm{~T} 5)\end{array}$ & $\begin{array}{l}\text { Meningkatkan profesionalisme } \\
\text { pengelolaan, wahana bermain, fasilitas } \\
\text { umum serta inovasi dan kreatifitas untuk } \\
\text { menjaga persaingan antar Balkondes dan } \\
\text { objek wisata lainnya sehingga tingkat } \\
\text { kunjungan wisata tinggi dan mampu } \\
\text { memberikan kesan positif yang memorable } \\
\text { bagi pengunjung serta berdampak pada } \\
\text { tingginya kentungan objek wisata (W1, W2 } \\
\text { W4, W5, T1, T2, T4, T5,T6,T8) }\end{array}$ \\
\hline $\begin{array}{lr}\text { Dominasi } & \text { pengunjung } \\
\text { millenial yang } \\
\text { menginginkan adanya } \\
\text { inovasi berkelanjutan }\end{array}$ & & $\begin{array}{l}\text { Memaksimalkan promosi guna } \\
\text { mengenalkan Balkondes Ngadihajo kepada } \\
\text { Masyarakat secara lebih luas serta } \\
\text { mencakup semua usia hingga luar wilayah } \\
\text { Magelang (W3, T1, T3) }\end{array}$ \\
\hline \multicolumn{3}{|l|}{$\begin{array}{l}\text { Pengunjung } \\
\text { didominasi wisatawan } \\
\text { lokal Magelang }\end{array}$} \\
\hline \multicolumn{3}{|l|}{$\begin{array}{l}\text { Akses jalan yang } \\
\text { masih sulit dijangkau } \\
\text { karena berada di } \\
\text { pedesaan }\end{array}$} \\
\hline $\begin{array}{l}\text { Tidak tersedianya } \\
\text { public trasportation }\end{array}$ & & \\
\hline
\end{tabular}

Sumber: Hasil Penelitian, 2020

Tahap pemaduan adalah proses memadukan elemen kekuatan, kelemahan, peluang dan ancaman dengan menggunakan Matriks SWOT yang dilakukan setelah menganalisis faktor internal dan faktor eksternal dengan tujuan menentukan strategi alternative pengembangan Balkondes Ngadiharjo. Strategi tersebut meliputi strategi SO, WO, ST, dan WT.

1. Strategi Strengths-Opportunities (S-O)

Strategi S-O ialah strategi yang memanfaatkan kekuatan internal untuk memanfaatkan peluang eksternal guna memperoleh keuntungan bagi Balkondes Ngadiharjo. Beberapa alternatif strategi S-O yang dihasilkan adalah sebagai berikut:

a. Mengoptimakan keberadaan Balkondes yang berada pada satu Kecamatan dengan Candi Borobudur serta daya tarik dan kekhasan Balkondes untuk menarik pengunjung dalam jumlah yang lebih tinggi yang mencakup segala usia melalui berbagai promosi dengan memanfaatkan tingginya akses internet sehingga dapat meningkatakan dampak positif perekonomian masyarakat sekitar.

Strategi ini didasari oleh adanya daya tarik berupa pemandangan di sekitar balkondes yang dipadukan dengan kreatifitas dan dekorasi yang menarik serta keberadaannya yang terletak pada satu kecaman yang sama dengan Candi Borobudur sehingga dapat memberikan efek positif akan banyaknya wisatawan. Hal ini tentunya dapat memberikan dampak terhadap peningkatan perekonomian masyarakat sekitar

b. Mengoptimalkan rendahnya tarif tiket masuk, paket wisata, keindahan dan luasnya lokasi serta ketersediaan fasilitas yang cocok untuk bermacam event berbagai kelompok.

Strategi ini didasari oleh rendahnya tarif tiket yang bertujuan memperoleh banyaknya pengunjung dari segala segmen dan juga organisasi untuk berwisata serta berkegiatan di Balkondes Ngadiharjo

c. Mengajak masyarakat sekitar untuk ikut berperan aktif dalam kegiatan promosi serta menjaga dan meningkatkan sense belonging, keramahan serta dukungan masyarakat sekitar yang secara tidak langsung memberikan kesan positif sehingga memunculkan keinginan pengunjung untuk kembali dan merekomendasikan kepada orang lain.

Strategi S-O yang ini didasari akan pentingnya mengajak masyarakat sekitar untuk turut serta melakukan promosi baik secara langsung menggunakan berbagai media dan secara tidak langsung berupa keramahan yang akan memberikan rasa aman dan nyaman bagi pengunjung

d. Mengoptimalkan kecenderungan wisatawan yang beralih dari mass tourism ke niche tourism berbasis lingkungan untuk memperoleh wisatawan yang lebih banyak dengan menawarkan pemandangan alam yang menarik, berbagai kuliner dan souvenir serta kekhasan yang dimiliki Bakondes Ngadiharjo.

Strategi ini didasari akan adanya peningkatan prospek wisata berbasis lingkungan yang sejalan dengan yang ditawarkan Balkondes Ngadiharjo berupa pemandangan alam yang 
menarik, berbagai kuliner dan souvenir serta kekhasannya untuk memperoleh wisatawan yang lebih banyak.

2. Strategi Weakness-Opportunities (W-O)

Strategi W-O merupakan strategi yang disususun untuk mengatasi kelemahan dengan memanfaatkan peluang yang ada. Beberapa alternatif strategi yang dihasilkan adalah sebagai berikut:

a. Mengoptimalkan banyaknya wisatawan Candi Borobudur untuk berwisata ke Balkondes Ngadiharjo melalui promosi yang masif dengan biaya yang murah untuk mencapai tingkat keuntungan yang tinggi

Stategi ini disarankan untuk mangatasi rendahnya keuntungan yang didapat pada setiap bulannya, oleh karenanya diperlukan promosi dengan berbagai cara baik konvensional maupun secara elektronik dengan biaya yang terjangkau untuk menarik wisatawan Candi Borobudur untuk turut berkunjung ke Balkondes Ngadiharjo

b. Mengoptimalkan banyaknya organisasi/kelompok yang menggelar outdoor event dan kecenderungan berwisata niche tourism berbasis lingkungan serta tingginya keinginan wisatawan untuk berkunjung kembali dan merekomendasikan kepada orang lain dengan diimbangi oleh ketersediaan wahana yang manarik serta fasilitas yang memadai

Strategi tersebut direkomendasikan guna memperoleh pengunjung berskala besar berupa organisasi/kelompok ditengah perubahan perilaku wisatawan yang berbasis lingkungan serta tingginya pengunjung yang ingin berkunjung kembali serta merokemendasikan kepada orang lain

3. Strategi Strength-Threats (S-T)

Strategi S-T merupakan strategi yang dibuat dengan menggunakan kekuatan internal untuk menghindari atau mengurangi dampak ancaman eksternal bagi Balkondes Ngadiharjo. Alternatif strategi S-T yang dihasilkan yaitu meningkakan kreativitas, inovasi serta kekhasan yang dimiliki Balkondes Ngadiharjo untuk menjaga persaingan jumlah pengunjung antar Balkondes dan wisata lainnya. Strategi ini didasari akan perlunya menjaga persaingan untuk memperoleh banyak pengunjung ditengah tingginya persaingan antar balkondes maupun objek wisata lainnya, oleh karenanya sangat penting untuk meningkatkan kreativitas dan inovasi berkelanjutan serta menonjolkan ciri khas yang dimiliki.

4. Strategi Weakness-Threats $(\mathrm{W}-\mathrm{T})$

Strategi W-T merupakan strategi yang diusulkan untuk mengurangi kelemahan internal dan menghindari ancaman eksternal yang ada. Beberapa alternatif strategi $\mathrm{W}-\mathrm{T}$ yang dihasilkan adalah sebagai berikut:

a. Meningkatkan profesionalisme pengelolaan, wahana bermain, fasilitas umum serta inovasi dan kreatifitas untuk menjaga persaingan antar Balkondes dan objek wisata lainnya sehingga tingkat kunjungan wisata tinggi dan mampu memberikan kesan positif yang memorable bagi pengunjung serta berdampak pada tingginya keuntungan objek wisata
Strategi ini didasari oleh adanya kelemahan seperti rendahnya profesionalitas pengelolaan, inovasi dan kreatifitas yang dikhawatirkan dapat menurunkan jumlah kunjungan wisata. Oleh karenanya para pengelola harus terus berupaya meningkatkan profesionalitas pengelolaan, inovasi serta kreatifitas sehingga Balondes Ngadiharjo akan terus mampu bersaing dengan objek wisata lain sejenis

b. Memaksimalkan promosi guna mengenalkan Balkondes Ngadihajo kepada Masyarakat secara lebih luas serta mencakup semua usia hingga luar wilayah Magelang

Strategi terakhir ini dilatarbelakangi oleh kunjungan wisata yang masih sebatas wisatawan lokal dari daerah Magelang, oleh karena promosi harus ditingkatkan agar objek wisata ini dapat dikenal secara luas yang mencakup semua usia hingga masyarakat luar wilayah Magelang.

\section{KESIMPULAN}

Alternatif strategi pengembangan Balkondes Ngadiharjo antara lain (1) Strategi StrengthsOpportunities meliputi pengoptimalan promosi, akses internet, fasilitas yang cocok mengingat luasnya lokasi, wisata berbasis lingkungan, mengajak masyarakat dalam meningkatkan sense belonging, keramahan serta dukungan pada pengunjung Balkondes; (2) Strategi Weakness-Opportunities meliputi pengoptimalan wisatawan Candi Borobudur untuk berwisata ke Balkondes Ngadiharjo, outdoor event dan kecenderungan berwisata niche tourism berbasis lingkungan; (3) Strategi Strength-Threats meliputi meningkakan kreativitas, inovasi serta kekhasan yang dimiliki Balkondes Ngadiharjo untuk menjaga persaingan jumlah pengunjung antar Balkondes dan wisata lainnya; (4) Strategi Weakness-Threats meliputi memaksimalkan promosi yang mencakup semua usia hingga luar wilayah Magelang, meningkatkan profesionalisme pengelolaan, wahana bermain, fasilitas umum serta inovasi dan kreatifitas untuk menjaga persaingan antar Balkondes dan objek wisata lainnya sehingga tingkat kunjungan wisata tinggi dan mampu memberikan kesan positif yang memorable bagi pengunjung serta berdampak pada tingginya keuntungan objek wisata

\section{DAFTAR PUSTAKA/REFERENSI}

Badan Pusat Statistik. (2019). Laporan Perekonomian Indonesia 2019. In Badan Pusat Statistik Indonesia.

Badan Pusat Statistik Indonesia. (2019). Tingkat Penghunian Kamar pada Hotel Bintang Menurut Provinsi (Persen) Tahun 2004-2018. https://www.bps.go.id/dynamictable/2020/01/14/1760/ tingkat-penghunian-kamar-pada-hotel-bintang-menurutprovinsi-persen-2004-2018.html

Bahiyah, C., R, W. H., \& Sudarti. (2018). Strategi Pengembangan Potensi Pariwisata di Pantai Duta Kabupaten Probolinggo. Jurnal Ilmu Ekonomi, 2(1), 95-103. http://ejournal.umm.ac.id/index.php/jie/article/view/69 
Vol. 8 No 2, 2020

70.

BPS Provinsi Jawa Tengah. (2018). Realisasi Penerimaan Pajak Jawa Tengah Menurut Klasifikasi Lapangan Usaha Juta Rupiah) Tahun 2016-2018. Badan Pusat Statistik. https://jateng.bps.go.id/dynamictable/2019/12/11/632/ realisasi-penerimaan-pajak-jawa-tengah-menurut-

klasifikasi-lapangan-usaha-juta-rupiah-2016-2018.html

Cholisna, S. L., Setiyaningrum, D., Kumala, F., \& Yuliani, N. L. (2019). Contribution of BALKONDES " Saka Pitu " As A Supporter of Borobudur KSPN in Increasing Economy of Tegalarum. Jurnal Analisis Bisni Ekonomi, 17(2), 125-134.

Darmanahia, G. (2019). Metodologi Penelitian. CV. Hira Tech.

Deddy Prasetya Maha Rani. (2014). PENGEMBANGAN POTENSI PARIWISATA Kabupaten Sumenep, Madura, Jawa Timur (Studi Kasus: Pantai Lombang). Jurnal Politik Muda, 3(3), 412-421.

Devy, H. A., \& Soemanto, R. B. (2017). Pengembangan Obyek Dan Daya Tarik Wisata Alam Sebagai Daerah Tujuan Wisata Di Kabupaten Karanganyar (Studi Kasus Obyek Wisata Air Terjun Jumog di Kawasan Wisata Desa Berjo, Kecamatan Ngargoyoso, Kabupaten Karanganyar). Jurnal Sosiologi DILEMA, 32(1), 34-44.

Hidayah, A. N., \& Agustinah, R. (2019). Balkondes Candirejo Magelang Sebagai Bentuk Pengembangan Desa Wisata Yang Berkelanjutan. Jurnal Komunikasi Dan Kajian Media, 3(1), 70-89. https://doi.org/10.31227/osf.io/g6pt2

Muafi, Sugandini, D., \& Susilowati, C. (2018). Pemberdayaan Masyarakat Melalui Pendekatan Community Based Tourism Di Desa Kepakisan Dataran Dieng. Jurnal Abdimas Unmer Malang, 3(1), 48-54.

Nurcahya, E., \& Alexandri, M. B. (2020). Analisis Swot Strategi Penanggulangan Kemiskinan Di Kota Bandung. Jurnal MODERAT, 6(2), 257-267. https://jurnal.unigal.ac.id/index.php/moderat/article/vie $\mathrm{w} / 3354$

Pajriah, S. (2018). Peran Sumber Daya Manusia Dalam Pengembangan Pariwisata Budaya DI Kabupaten Ciamis. Jurnal Artefak: History and Education, 5(1), 25-34. https://doi.org/10.1017/СB09781107415324.004

Prihatsanti, U., Suryanto, \& Hendriani, W. (2018). Menggunakan Studi Kasus sebagai Metode Ilmiah dalam Psikologi. Buletin Psikologi, 26(2), 126-136. https://doi.org/10.22146/buletinpsikologi.38895

Rah Adi Fahmi, G., Setyadi, S., \& Suiro, U. (2018). Analisis Strategi Penanggulangan Kemiskinan Di Provinsi Banten. Jurnal Ekonomi-Qu, 8(2), 227-248. https://doi.org/10.35448/jequ.v8i2.4450

Tingginehe;, A. M., Waani;, J. 0., \& Wuisang, C. E. V. (2019). Perencanaan Pariwisata Hijau Di Distrik Roon Kabupaten Teluk Wondama, Papua Barat. Jurnal Spasial, 6(2), 511520. 